\title{
Apresentação do Dossiê "Novas universidades, novos campi, novas antropologias: docências, alteridades e expansão do Ensino Superior no Brasil"
}

Presenting the Special Issue "New Colleges, New Campi, New Anthropologies:

Teaching, Alterities and the Expansion of Higher Education in Brazil"

Natacha Simei Leal, Guillermo Vega Sanabria e Diógenes Egídio Cariaga

\section{(2) OpenEdition}

Journals

Edição electrónica

URL: http://journals.openedition.org/aa/7652

DOI: $10.4000 /$ aa.7652

ISSN: 2357-738X

Editora

Programa de Pós-Graduação em Antropologia Social (UnB)

Edição impressa

Paginação: 25-38

ISSN: 0102-4302

\section{Refêrencia eletrónica}

Natacha Simei Leal, Guillermo Vega Sanabria e Diógenes Egídio Cariaga, «Apresentação do Dossiê "Novas universidades, novos campi, novas antropologias: docências, alteridades e expansão do Ensino Superior no Brasil"», Anuário Antropológico [Online], v.46 n.1 | 2021, posto online no dia , consultado o 27 abril 2021. URL: http://journals.openedition.org/aa/7652 ; DOI: https://doi.org/ 10.4000/aa.7652 


\section{Apresentação do Dossiê: Novas universidades, novos campi, novas antropologias: docências, alteridades e expansão do Ensino Superior no Brasil}

Presenting the Special Issue:

New Colleges, New Campi, New Anthropologies: Teaching, Alterities and the Expansion of Higher Education in Brazil

DOI: https://doi.org/10.4000/aa.7652

Natacha Simei Leal • Universidade Federal do Vale do São Francisco - Brasil

Professora Adjunta do Colegiado de Antropologia da UNIVASF, campus Serra da Capivara. Doutora e mestra em Antropologia Social pela Universidade de São Paulo (USP), é pesquisadora associada ao Hybris (Grupo de Estudo e Pesquisa sobre Relações de Poder, Conflitos, Socialidades - USP/UFSCar), ao NuAP (Núcleo de Antropologia Política - UFRJ, Museu Nacional) e ao LaMPda (Laboratório de Metodologia, Pesquisa e Documentação em Antropologia, CANT - UNIVASF).

\section{Guillermo Vega Sanabria • Universidade Federal da Bahia - Brasil}

Doutor em Antropologia pelo PPGAS do Museu Nacional/UFRJ, é professor no curso de Ciências Sociais e no PPGA da UFBA. Coordena a Comissão de Educação, Ciência e Tecnologia da ABA e faz parte da diretoria da Teaching Anthropology Network da EASA. 
O presente dossiê foi desenvolvido em meio à crise criada pela pandemia da Covid-19, que colocou os autores e autoras em isolamento físico, escrevendo de suas casas, sem acesso direto às universidades e aos estudantes com quem trabalham. Foi preciso, então, aprender a lidar com as infindáveis reuniões e com as aulas em modo remoto que, a partir deste ano de 2020, certamente, nortearão novas práticas e políticas das instituições de ensino superior brasileiras. Tal fato merece registro. E não apenas em razão do luto e da preocupação dos autores e autoras com familiares, amigos, conhecidos (e também desconhecidos) assolados pelos efeitos do novo coronavírus, tal como menciona Thais Brito neste dossiê, mas, especialmente, porque as condições de possibilidade daquilo que é objeto fundamental deste conjunto de artigos - a pesquisa, o ensino e a extensão em Antropologia e em Ciências Sociais fora dos grandes centros de formação brasileiros - já vinham sendo impactadas pelos sucessivos cortes no financiamento e apoio às universidades públicas, mesmo antes da pandemia.

Por isso, nossas inquietações remontam a um tempo anterior. Este dossiê, em particular, é tributário dos debates ocorridos em duas mesas-redondas que levaram o mesmo título: Novas universidades, novos campi, novas antropologias: docências, alteridades e expansão do Ensino Superior no Brasil. A primeira, concebida e coordenada por Rafael da Silva Noleto (Universidade Federal de Pelotas, UFPel), aconteceu em 2018, na 31 ${ }^{\text {a }}$. Reunião Brasileira de Antropologia, realizada em Brasília, em mesa que contou com a participação de Rafael Antunes Almeida (Universidade da Integração Internacional da Lusofonia Afro-Brasileira, Unilab), Diógenes Egídio Cariaga (Universidade Estadual de Mato Grosso do Sul, Uems) e Natacha Simei Leal (Universidade Federal do Vale do São Francisco - Univasf). Já a segunda edição da mesa, ocorrida em 2019, na VI Reunião Equatorial de Antropologia, em Salvador, reuniu novamente Diógenes e Natacha e, teve ainda a participação de Guillermo Vega Sanabria (Universidade Federal da Bahia, UFBA) e de Bela Feldman-Bianco (Universidade Estadual de Campinas, Unicamp).

Os problemas e os desafios da expansão e da interiorização do ensino superior debatidos nessas ocasiões, especialmente a partir das políticas públicas de meados dos anos 2000, como o Programa de Expansão da Educação Superior Pública (Expandir, 2003-2006) e do Programa de Apoio a Planos de Expansão e Reestruturação de Universidades Federais (Reuni, 2007-2012), foram acrescidas das calorosas questões colocadas por estudantes e docentes que também participaram dessas mesas. Suas contribuições nos estimularam a convidar outros antropólogos e antropólogas, que trabalham ou trabalharam em universidades cujos campi estão localizados em pequenas cidades do interior do Brasil, a tornarem públicas suas práticas pedagógicas, suas relações com a comunidade e seus dilemas profissionais, analisados brilhantemente nos artigos que compõem o presente dossiê.

Os seis textos revelam a multiplicidade de antropologias produzidas no interior do país. As experiências de jovens doutores e doutoras atuando em pequenas cidades dos estados do Amazonas (Melo e Reis), Bahia (Brito; De Lucca e Buti), Piauí (Leal), Mato Grosso do Sul (Cariaga) e Minas Gerais (Vega Sanabria) demonstram aquilo que Flávia Melo e Rodrigo Reis enunciam em seu artigo acerca 
da antropologia brasileira: uma ciência cada vez mais "diversificada, sofisticada e vanguardista", cujas qualidades, como igualmente defendem os autores, não podem ser dissociadas das políticas de expansão e de interiorização das universidades. Em que pesem as limitações desse processo (cfr. os trabalhos reunidos por Simião e Feldman-Bianco, 2018, pelo menos no que tange aos cursos de pós-graduação), tem sido no encalço dessas políticas que, paulatinamente, registra-se a formação de antropólogas e antropólogos oriundos de grupos populares e periféricos dos mais diversos, não apenas das elites e das classes médias urbanas. Em que pese também o fato de que, a rigor, essa aparente diversidade continua sendo um problema que merece ser mais estudado empiricamente, ela é um corolário dos trabalhos aqui apresentados. Nesse sentido, o dossiê é um convite e busca servir de estímulo para que indagações mais amplas e sistemáticas possam ser realizadas no futuro.

A reflexão proposta nos seis artigos é feita a partir da inserção dupla de seus autores e autoras: a de professores e a de antropólogos, com base na reflexividade que é marca da própria antropologia. Vega Sanabria, por exemplo, apela à ideia de "dupla marginalidade" e de "liminaridade" para discernir sua posição em um curso de Ciências Sociais na Universidade Federal de Viçosa (UFV), uma instituição notadamente marcada pela centralidade do agronegócio e das ciências agrárias. De Lucca e Buti se valem das noções de "Atlântico Negro" e de "ouro negro" a fim de analisar a interiorização e a internacionalização na Unilab, no Recôncavo Baiano, por meio da descrição de experiências africanas e quilombolas com a Refinaria de petróleo Landulpho Alves-Mataripe. Leal articula as contribuições sobre os efeitos do incêndio do Museu do Nacional com autores e autoras que vêm pensando "fim de mundos e modos de existir" para descrever os impasses e desafios da recente fundação de um curso de Antropologia na Univasf, em São Raimundo Nonato (PI), em um momento de sucessivos cortes de recursos e ataques à legitimidade das Ciências Humanas e Sociais.

Cariaga, por sua vez, se vale de reflexões etnológicas sobre as relações ameríndias com o mundo dos brancos para descrever a expressiva presença de alunos e alunas Guarani-Kaiowá na Uems, em Amambai (MS). A presença indígena na universidade é igualmente objeto do texto de Melo e Reis sobre o primeiro Bacharelado de Antropologia do país, na Universidade Federal do Amazonas (Ufam), que compõe, com a descrição de projetos de extensão sobre violência de gênero na mesma instituição, a potência das pesquisas "contaminadas", presentes e decisivas para o campus de Benjamin Constant (AM). Já Thais Brito, a partir do relato sobre sua chegada para atuar num Bacharelado Interdisciplinar da então recém-criada Universidade Federal do Recôncavo Baiano (UFRB), descreve como experimentou Santo Amaro (BA) enquanto uma "cidade-laboratório" e, concomitantemente, se viu transformada como um "experimento" das bordadeiras da Ilha do Dendê, com quem passou a trabalhar em um projeto de extensão.

$\mathrm{Na}$ diversidade de experiências e abordagens trazida pelos artigos existem algumas confluências. A primeira é um posicionamento político comum aos autores e autoras e que está na origem da própria organização do dossiê: a defesa 
inequívoca da universidade pública, gratuita e de qualidade. A reflexão sobre as condições em que foi feita e os desdobramentos da mais recente expansão contribui para pensarmos como ela ainda é imperativa e incompleta. Isso exige, inevitavelmente, como fica claro nas tensões apontadas pelos trabalhos aqui reunidos e bem observou Almeida (2019), renunciar ao ufanismo e a uma leitura apologética da "década de ouro". Ademais, é preciso, nas palavras de Melo e Reis, chamar a atenção para a "penosidade" de habitar as fronteiras e os outros territórios da geografia nacional onde se encontram as novas universidades, os novos campi e os novos cursos de graduação e de pós-graduação.

A segunda confluência é da ordem das escalas das cidades onde os autores e autoras trabalham e sobre as quais escrevem. É certo que a criação de universidades públicas no interior não é exatamente uma novidade na história do ensino superior brasileiro e que ressalvas podem ser feitas sobre a própria ideia de "interior", tal como sugere o artigo de Vega Sanabria sobre a quase centenária UFV. Contudo, alguns elementos merecem ser ponderados nesse sentido, como o maior ou menor afastamento dessas cidades das capitais estaduais ou do litoral e o tamanho de suas populações. Por exemplo, São Francisco do Conde está a 67 quilômetros de Salvador enquanto São Raimundo Nonato a 550 de Teresina e Benjamin Constant a 1.118 de Manaus. Por outra parte, todas têm menos de 80 mil habitantes: Viçosa tem 79.388, Santo Amaro tem 60.131, Benjamin Constant tem 43.935, São Francisco do Conde tem 40.245, Amambai tem 39.826 e São Raimundo Nonato tem 34.877. Haja vista eventuais especificidades regionais e geográficas, assim como o acesso diferenciado a redes de serviços e a órgãos estatais, outra pergunta empírica que surge nesta seara é, precisamente, o que torna esses municípios mais ou menos "interiorizados" e quais transformações têm experimentado recentemente, inclusive relacionadas à implantação de instituições de ensino superior em seus territórios.

Neste sentido, por exemplo, na chamada para a coletânea "O papel das instituições de ensino superior na interiorização do desenvolvimento brasileiro", lançada em 2019 pelo Instituto de Pesquisa Econômica Aplicada (IPEA) e pelo Ministério do Desenvolvimento Regional (MDR), apontava-se que a expansão do sistema nacional de ensino superior pode ser considerada um vetor da dinâmica urbana e regional brasileira, pelo menos até a crise econômica de 2014. Essa dinâmica, por sua vez, estaria relacionada ao "caráter mais interiorizado e menos metropolitano da produção brasileira, com cidades pequenas e intermediárias crescendo acima da média da economia nacional" (especialmente na agroindústria de exportação e/ou da indústria extrativa, também de exportação). Com o crescimento do investimento federal, tanto na rede pública quanto na privada, para ocupação e aumento do número de vagas, um conjunto de municípios de pequeno e médio porte - localizados em microrregiões não atendidas ou atendidas apenas precariamente pela oferta de educação terciária - passou a integrar o sistema nacional de ensino superior, ampliando suas perspectivas de desenvolvimento local (IPEA/ MDR, 2019). Parte dos artigos neste dossiê aponta, de fato, para as oportunidades criadas nesses pequenos municípios que recebem novas universidades e novos 
campi pela dinamização da economia local, como avalia Leal a respeito da presença de um campus da Univasf na Serra da Capivara.

Porém, eles trazem, igualmente, conflitos, como os descritos por De Lucca e Buti sobre a relação da população de São Francisco do Conde com os estudantes africanos, tratados como "estrangeiros" (que seriam favorecidos pela universidade em detrimento dos habitantes locais ou dos estudantes nacionais) e vistos com desconfiança por causa da religião muçulmana. Alianças e relações políticas diversas, em âmbito local e nacional, também aparecem nos textos. Os alunos e alunas de Diógenes Cariaga, por exemplo, afirmam que a presença indígena na Uems de Amambai só é possível em razão do transporte escolar da Prefeitura, que os leva e traz entre suas aldeias e o campus da universidade. Thais Brito descreve a mobilização coletiva das autoridades locais e as redes de políticos regionais em Santo Amaro pela instalação da UFRB naquele município que, "desde sempre”, foi um lugar de "cultura".

Por fim, outra confluência merece destaque. Os oito autores e autoras que contribuíram com este dossiê cursaram suas pós-graduações no eixo Sul-Sudeste: três se formaram na Universidade de São Paulo, dois no Museu Nacional (Universidade Federal do Rio de Janeiro), dois na Universidade Federal de Santa Catarina e um na Unicamp. Este é um indicador interessante: jovens doutores e doutoras estão circulando e construindo suas carreiras em novas instituições, diferentes daquelas onde se formaram e se deslocando para outras regiões. Por outro lado, evidencia uma certa assimetria, já destacada por Igor Machado (2018), em artigo sobre os egressos de doutorados em antropologia no Brasil: se os formados no Sul e no Sudeste têm alta empregabilidade em todo o país, os formados em outras regiões, mesmo com pós-graduações antigas e consolidadas, têm um espaço de atuação muito mais restrito geográfica e institucionalmente, conseguindo se empregar quase que exclusivamente nas regiões onde se formaram. Assim, por exemplo, os formados no Norte, no Nordeste e em parte do Centro-Oeste têm mais chances de se vincularem a instituições dessas regiões e muito menos chances de se empregarem em instituições do Sul e do Sudeste.

$\mathrm{O}$ fato de que os autores e autoras aqui reunidos tenham se formado em programas de reconhecida excelência nacional e internacional, tacitamente visando o trabalho como docentes e pesquisadores, também coloca estes jovens doutores diante de outros desafios na gestão de suas carreiras acadêmicas. Os antropólogos que contribuíram com esse dossiê, como tantos outros que atuam em novas universidades, novos campi e cursos no interior, compartilham, decididamente, de um certo entusiasmo de contribuírem para a construção e consolidação de algo novo. Contudo, com o passar dos anos, o entusiasmo inicial, por vezes, transforma-se em angústia e frustração em face das limitações que enfrentam. Especialmente, no que diz respeito à mobilidade (longas distâncias agravadas pela precariedade do transporte terrestre ou pela falta de transporte aéreo); ao acesso a serviços, em particular os relacionados à saúde, à educação infantil e básica para os filhos e à burocracia estatal (inclusive na gestão da própria universidade), assim como aos de lazer e recreação, mas, sobretudo, às possibilidades de acesso ao financiamento 
da pesquisa e de atuação na pós-graduação. Assim, neste quadro, não são raras as remoções, redistribuições e mesmo as buscas por novos concursos.

A constatação de que o trabalho nos novos campi do interior quase sempre se restringe ao ensino na graduação coloca problemas não apenas para os docentes. Onde os estudantes egressos das novas universidades do interior brasileiro se empregarão ou darão continuidade às suas formações? Se optarem por uma carreira acadêmica, eles terão, necessariamente, de se formar em programas de pós-graduação consolidados em grandes cidades para conseguir uma colocação nas universidades públicas ou em outras instituições? E os programas consolidados, haja vista os avanços nas políticas de ação afirmativa e de inclusão estudantil, estão, de fato, atentos e preparados para receber os alunos indígenas, quilombolas e mesmo os "filhos de agricultores" que mais recentemente tiveram acesso à universidade?

A UFRB de Thais Brito, assim como a Unilab de Daniel Lucca e Rafael Butti, por exemplo, ainda não possuem campi próprios. Natacha Leal descreve as dificuldades de acesso a recursos para pesquisas em ciências humanas na Univasf, uma universidade da "inovação" no pujante polo agrícola do Vale do São Francisco. Diógenes Cariaga narra que, apesar do curso de Ciências Sociais da Uems ter completado 12 anos e contar com a presença massiva de estudantes indígenas, foi só em 2019 que os primeiros professores efetivos da área de antropologia foram contratados. Tais precariedades e restrições podem tornar o trabalho de pesquisa, ensino, extensão e gestão universitária ainda mais árduo do que é nos grandes centros de formação, e ecoam na perspicaz análise de Vega Sanabria, a partir de sua experiência em Viçosa, como alguém que "tinha chegado para ficar", mas que acabou por vir a atuar em outra instituição.

\section{O alcance da expansão e da interiorização e o futuro da universidade pública}

Embora o ensino tenha sido objeto de interesse de longa data na antropologia no Brasil (cfr. Vega Sanabria; Duarte, 2019), o presente dossiê tem um certo ineditismo ao lançar luz, em um nível local, sobre as condições em que foram criadas e funcionam universidades, campi e cursos no embalo do último processo de expansão. Outros trabalhos já têm apontado alguns efeitos deste processo em termos institucionais, na antropologia como "área" no sistema de ensino superior nacional (ver, por exemplo, Simião; Feldman-Bianco, 2018), assim como nos cursos de pós-graduação (ver Almeida, 2019 para os novos cursos na Amazônia). Contudo, pouco sabemos ainda dos seus desdobramentos no ensino de graduação ou na pesquisa e na extensão em antropologia nestes novos contextos e à luz das características gerais do sistema universitário nacional.

Em geral, pelo menos entre nós, antropólogos, parece haver uma visão otimista e elogiosa da expansão e da interiorização. Em parte, porque a análise deste processo parece se confundir com a análise do efeito (positivo) das políticas de ação afirmativa e de inclusão no ensino superior. Contudo, esse quadro vem sendo 
objeto de uma atenção cada vez mais cuidadosa, que permite ponderar melhor o alcance efetivo da mais recente expansão. Isso parece especialmente verdadeiro no que diz respeito às travas e às desigualdades seculares do nosso sistema universitário, como apontam, por exemplo, os trabalhos reunidos pela socióloga Maria Lígia de Oliveira Barbosa, na coletânea "A expansão desigual do ensino superior no Brasil” (2020). Nas palavras desta autora, "com quase 8 milhões e meio de estudantes no ensino superior, o Brasil comemora a expansão do número de matrículas, mas não avança na redução da desigualdade social”. Daí que, como também observa Barbosa, "é preciso examinar mais de perto o que vem acontecendo para avaliar em que grau a educação superior contribui ou não para esse acirramento das desigualdades sociais que parece estar associado à expansão das matrículas" (2020: 13 e 22).

No artigo "O perfil institucional do sistema de ensino superior brasileiro após décadas de expansão", Santos, Lima e Carvalhaes (2020) chamam atenção para o papel do Plano Nacional da Educação de 2001 como importante indutor das políticas de expansão até 2011, especialmente do ponto de vista do aumento das matrículas. O Reuni, lançado em 2007, também estimulou o aumento de vagas, sobretudo no período noturno, a criação de novos campi em cidades do interior e a adoção de políticas inclusivas nas instituições federais. A partir dessas e de outras ações oficiais, entre 2002 e 2014, o número de universidades federais subiu de 43 para 63 (em 2020, o número de universidades federais é de 69) e o de campi passou de 148 para 321. Também foram criados 38 Institutos Federais de Educação, Ciência e Tecnologia (IFETs), no âmbito da Rede Federal de Educação Profissional, Científica e Tecnológica, por meio da Lei n ${ }^{\circ}$ 11.892, de dezembro de 2008.

Como observam Santos, Lima e Carvalhaes, uma parcela importante da expansão consistiu, igualmente, no estímulo às instituições de ensino superior privadas por meio do financiamento público indireto, via renúncias fiscais do Programa Universidade para Todos (Prouni) e da ampliação da cobertura do Fundo de Financiamento Estudantil (Fies). Dados apresentados na chamada do Ipea e MRD (2019), mostram que, em 2017, os contratos em utilização (estoque) do Fies passaram de aproximadamente 182 mil para 1,9 milhões entre 2009 e 2015. Isso significa um acréscimo médio de 280 mil matrículas por ano. Assim, as matrículas vinculadas a este Fundo foram de aproximadamente 5\% para 39\% do total de matrículas da rede privada. O Prouni, por sua vez, tem ampliado a oferta de bolsas desde 2005; a oferta que, nesse ano, tinha sido de 112.275 foi para 417.276 em 2018.

No entanto, o relatório Education at a Glance 2019 (EAG 2019), da Organização para a Cooperação e o Desenvolvimento Econômico (OCDE), oferece uma perspectiva comparada dos problemas enfrentados pelo Brasil no acesso à educação superior e no investimento por aluno ${ }^{1}$. Os dados brasileiros, providos pelo Instituto Nacional de Estudos e Pesquisas Educacionais (Inep), junto aos de outros 46 países, mostram que, apesar de a porcentagem de jovens adultos (25-34 anos) com diploma superior ter dobrado no prazo de uma década, o Brasil ainda mantém taxas de acesso abaixo da média da OCDE e de outros países latino-americanos. Segundo o relatório, em 2008, 11\% dos brasileiros de 25-34 anos tinham diploma de
1 Informações tomadas do site da Associação de Jornalistas da Educação (Jeduca). Disponível em: https://jeduca.org.br/texto/ estudo-da-ocde-revela-desafios-da-educacao-superior-no-brasil. Acesso em: 12 jun. 2020. Para uma apresentação dos dados referidos ao Brasil, consulte-se também o documento Panorama da educação. Destaques do Glance 2019, publicado pelo Inep. Disponível em: http://download.inep.gov. br/acoes_internacionais/eag/ documentos/2019/Panorama_ da_Educacao_2019.pdf Acesso em: 12 jun. 2020. 
nível superior. Em 2018, eram 21\%. O dado brasileiro é comparável ao do México, mas está abaixo de outros países latino-americanos, como Chile (25\%) e Argentina (36\%). Essa porcentagem corresponde à metade da média dos países da OCDE.

As diferenças aumentam e os indicadores do Brasil caem drasticamente quando referidos à pós-graduação no contexto dos países da OCDE. Aqui como lá, é uma minoria que chega a esses níveis, mas no Brasil a seletividade é ainda maior. Segundo o EAG 2019, somente 0,8\% dos brasileiros entre 25 e 64 anos têm título de mestre. Na OCDE, a média é de $13 \%$. A porcentagem dos que chegam ao doutorado é ainda menor: 0,2\% da população de 25 a 64 anos. Na OCDE, a média é de 1,1\%. Um dos elementos centrais na análise do reduzido acesso ao ensino superior no Brasil vincula-se às baixas taxas de conclusão do Ensino Médio e à concentração da oferta de vagas em instituições privadas, como fica evidente pelos dados do Censo da Educação Superior (ver tabela e gráfico abaixo). Outro elemento é, decerto, a eficiência do sistema e a permanência dos estudantes que ingressam no ensino superior. Nesse sentido, as condições e a qualidade do ensino são fundamentais, como o trabalho de Vega Sanabria, neste dossiê, chama atenção. Ademais, diante dos estrondosos cortes no financiamento público da educação superior, as políticas de inclusão e, sobretudo, de permanência de estudantes tornam-se mais do que nunca necessárias.

\begin{tabular}{l|l|c|c|c|c|c|c|c|c|}
\multirow{2}{*}{ ANO } & \multirow{2}{*}{ TOTAL } & \multicolumn{2}{|c|}{ UNIVERSIDADE } & \multicolumn{2}{c|}{$\begin{array}{c}\text { CENTRO } \\
\text { UNIVERSITÁRIO }\end{array}$} & \multicolumn{2}{c|}{ FACULDADE } & \multicolumn{2}{c|}{ IF E CEFET } \\
\cline { 3 - 10 } & & PÚBLICA & PRIVADA & PÚBLICO & PRIVADO & PÚBLICA & PRIVADA & PÚBLICO & PRIVADO \\
\hline 2018 & 2.537 & 107 & 92 & 13 & 217 & 139 & 1.929 & 40 & n.a.* \\
\hline
\end{tabular}

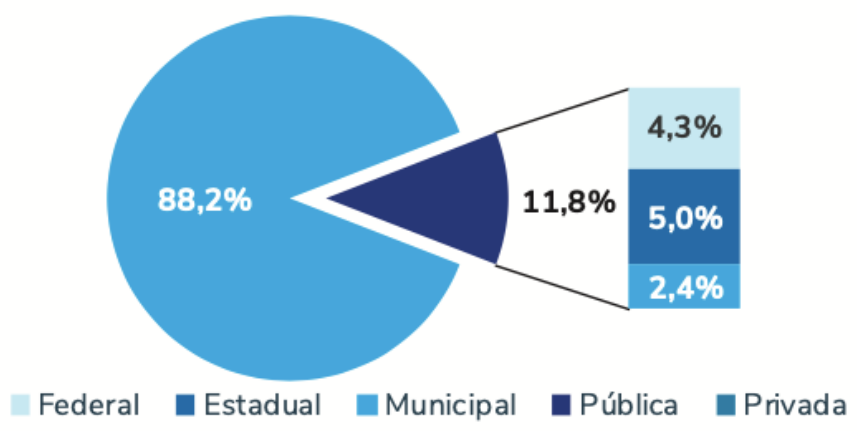

Conforme constatam Santos, Lima e Carvalhaes, apesar do impacto positivo que o Reuni teve na rede federal, não foi suficiente para acompanhar o ritmo de crescimento ditado pelas instituições privadas - entre 2002 e 2016, 82,3\% do crescimento das matrículas ocorreu por meio da rede privada (2020, p. 46-47). O Censo da Educação Superior 2018 (Brasil, 2019, p. 8) registra a existência de 299 Instituições de Educação Superior (IES) públicas e 2.238 IES privadas no Brasil:

- $\quad$ Em relação às IES públicas: $42,8 \%$ são estaduais (128); 36,8\% são federais (110); e 20,4\% são municipais (61);

- A maioria das universidades é pública (53,8\%);

- $\quad$ Entre as IES privadas, predominam as faculdades $(86,2 \%)$;
Tabela 1. Número de instituições de educação superior, por organização acadêmica e categoria administrativa - Brasil, 2018. Fonte: Brasil (2019, p. 7), com base em dados do Censo da Educação Superior, 2018. *Não se aplica. Gráfico 1. Percentual de instituições de educação superior, por categoria administrativa - Brasil, 2018. Fonte: Brasil (2019, p. 7), com base em dados do Censo da Educação Superior, 2018. 
- $\quad$ Das IES federais, 57,3\% correspondem às universidades, 36,4\% aos Institutos Federais de Educação, Ciência e Tecnologia (IFs) e Centros Federais de Educação Tecnológica (Cefets); 1,8\% às faculdades e 4,5\% são centros universitários.

Nesse quadro díspar entre rede pública e privada, é importante se perguntar, retomando a reflexão de Lígia Barbosa sobre expansão e desigualdade: "quem vai para qual curso em qual universidade?”. Ou, ainda, conforme afirmação de Thais Brito, nesse dossiê, refletir sobre o fato de que, talvez, o "ensino superior brasileiro acabou por incluir apenas os melhores e mais adaptados alunos das escolas públicas, ou seja, só atingimos uma parcela ínfima dos pretos e dos pobres”. Após o evidente aumento do acesso, cumpre observar, por exemplo, quanto à distribuição dos novos estudantes nos cursos universitários, que o fato de as mulheres serem maioria na educação superior, em modo algum significa que seu acesso seja igual ao dos homens, haja vista que elas se concentram sistematicamente em áreas menos valorizadas pelo mercado de trabalho. O mesmo pode ser dito quando considerados critérios raciais (Barbosa, 2020, p. 22, 24. Cfr. também Carvalhaes e Ribeiro, citados por Vega Sanabria neste dossiê). Pense-se, igualmente, do ponto de vista da permanência e do destino ocupacional dos egressos, de que modo "os cursos e suas especificidades são cruciais na definição das trajetórias desses estudantes, em especial de sua evasão"? (Barbosa, 2020, p. 23).

A seguinte tabela sintetiza o quadro do sistema universitário nacional desenhado após a expansão e já indica alguns desses problemas.

\begin{tabular}{|c|c|c|c|}
\hline \multirow{2}{*}{ Rede } & Pública & 787462 & $17.7 \%$ \\
\hline & Privada & 3671835 & $82.3 \%$ \\
\hline \multirow{2}{*}{ Modalidade } & Presencial & 3005593 & $67.4 \%$ \\
\hline & EAD & 1453704 & $32.6 \%$ \\
\hline \multirow{4}{*}{ Grau } & Bacharelado & 3210457 & $72.0 \%$ \\
\hline & Licenciatura & 708552 & $15.9 \%$ \\
\hline & Tecnológico & 826768 & $18.5 \%$ \\
\hline & Bac\&Lic & -286480 & $-6.4 \%$ \\
\hline \multirow{11}{*}{ Curso } & Administração & 1040714 & $23.3 \%$ \\
\hline & Engenharia e profissões correlatas & 1010381 & $22.7 \%$ \\
\hline & Saúde e bem estar social & 797696 & $17.9 \%$ \\
\hline & Direito & 397637 & $8.9 \%$ \\
\hline & Educação & 300868 & $6.7 \%$ \\
\hline & Ciências, matemática e computação & 288123 & $6.5 \%$ \\
\hline & Ciências sociais & 162849 & $3.7 \%$ \\
\hline & Agricultura e veterinária & 154568 & $3.5 \%$ \\
\hline & Arquitetura e urbanismo & 122351 & $2.7 \%$ \\
\hline & Humanidades e artes & 99267 & $2.2 \%$ \\
\hline & Serviços & 84843 & $1.9 \%$ \\
\hline
\end{tabular}

Tabela 2. Crescimento das matrículas no ensino superior brasileiro entre 2002 e 2016.

Fonte: Santos; Lima; Carvalhaes (2020, p. 48). 
No encalço do trabalho de Santos, Lima e Carvalhaes, que, nas suas palavras, trata-se de "análise do padrão de expansão mais desagregada disponível na literatura brasileira" (2020, p. 41), vale a pena citar aqui, sinteticamente, pelo menos três fatos apontados por esses autores:

- O bacharelado foi o grau mais importante da expansão do sistema universitário brasileiro entre 2002 e 2016, consolidando seu predomínio na formação universitária no país. $\mathrm{O}$ aumento da matrícula em cursos tecnológicos representou uma alternativa de diversificação do sistema, no que tange aos graus, enquanto os cursos de licenciatura foram os únicos que, apesar do crescimento absoluto das matrículas, diminuíram sua proporção relativa no conjunto do sistema. De fato, ao longo desses 14 anos, as licenciaturas experimentaram forte queda de seu peso nos cursos presenciais, tanto na rede pública quanto privada, cedendo espaço para a modalidade de educação a distância.

- A educação a distância, liderada pelo setor privado, foi o destaque em relação à variável "modalidade" e a que mais contribuiu para o volume de novas matrículas. Tendo crescido expressivamente apenas a partir de 2005, a educação a distância respondeu por 32,6 \% da expansão observada e representou outro vetor importante na diversificação do sistema. Como apontam Santos, Lima e Carvalhaes, "as mudanças na legislação em 2017, em termos de flexibilização da oferta, e atuação dos grandes grupos empresariais no ramo da educação superior sugerem um reforço desta tendência para os próximos anos” (2020, p. 51).

- Ao considerar os cursos, registra-se também uma redistribuição da importância relativa das áreas de conhecimento. Administração fortaleceu sua liderança e houve uma considerável expansão das Engenharias e dos cursos de Saúde e de "bem-estar social”. No caso da Engenharia, destaca-se a mudança da $7^{a}$ posição, em termos de concentração de matrículas em 2002, para a $2^{\mathrm{a}}$ posição em 2016. Áreas de conhecimento como Direito, Educação, Humanidades e Artes, Ciências Sociais, Ciências, Matemática e Computação perderam importância relativa. Constata-se, ainda, que, em 2016, as maiores áreas de conhecimento passaram a ter maior peso no sistema em termos de concentração de matrículas. Neste sentido, quando considerados os cursos, a diversidade do sistema universitário nacional diminuiu após a expansão. Os cursos impulsionados pela educação a distância não significaram maior diversificação, pois se concentram em áreas tradicionais como Administração e Educação. Com relação a esta última, "as mudanças experimentadas indicam que as instituições privadas assumiram a liderança nas matrículas de licenciatura e que as próximas gerações de professores brasileiros irão se formar na modalidade EaD” (Santos; Lima; Carvalhaes, 2020, p. 40, grifos nossos).

Muitas das questões levantadas pelos trabalhos reunidos neste dossiê, em termos institucionais, mas também das legítimas aspirações de professores e estudantes nos diversos locais que constituem o território nacional, precisam ser analisadas, discutidas e, quiçá, reformuladas em virtude deste quadro geral. Contudo, do ponto de vista de uma análise antropológica, algumas reflexões ainda merecem, pelo menos, ser aventadas. 


\section{Novas universidades para novas alteridades?}

Os textos que compõem este dossiê, como sugerido no início, apontam para uma multiplicidade de realidades e desafios provocados pelo aumento do número de matrículas no ensino superior brasileiro. Um deles, sem dúvida, coloca o futuro da universidade pública no centro de nossas reflexões e seu papel na redução de desigualdades históricas, em primeiro lugar no próprio âmbito educacional. Tem sido esta, aliás, a principal justificativa da criação de instituições como a Univasf, a Unilab e do conjunto das políticas de inclusão pelas ações afirmativas em instituições como a Uems.

Os artigos também chamam a atenção para o fato de que a expansão, a partir da instalação de novos campi no interior, não aconteceu à revelia das dinâmicas da política, projetos ou arranjos econômicos diversos, mas em clara consonância com eles. O texto de Guillermo Vega Sanabria relata o quanto a criação da Escola Superior de Agricultura e Veterinária, em 1922, décadas depois transformada em UFV, foi motivada pelos interesses das oligarquias regionais comprometidas com os projetos de modernização e desenvolvimento da nação. Flavia Melo e Rodrigo Reis notam que a instalação de um campus da Ufam em uma região de tríplice fronteira internacional segue um movimento semelhante, no sentido de assegurar "o tamanho do Brasil". O artigo de Natacha Leal demonstra que a criação da Univasf remonta a disputas regionais entre políticos pernambucanos e baianos, na busca por criar uma universidade federal com sede no interior, equacionadas somente com a proposta de uma universidade multicampi no Governo Lula. De Lucca e Butti, por sua vez, analisam a influência decisiva da primeira prefeita negra de São Francisco do Conde para a instalação de um campus da Unilab naquele município.

Assim, os autores e autoras demonstram que a criação de novos campi e universidades se associa a diferentes linhas de investimento para potencializar vocações econômicas de produção agrícola, energética e mesmo cultural. Concomitantemente, descrevem que as atividades que realizam nestes novos campi, aliadas, sobretudo, à presença de estudantes mulheres, indígenas, quilombolas, africanos ou camponeses, são capazes de subverter os sentidos mais consolidados da pesquisa, do ensino e da extensão e inclusive daquilo que entendemos por antropologia e o que este campo de conhecimento é capaz de produzir. Como observa Vega Sanabria, no início do seu artigo,

...se, como é dito amiúde, a criação de novos cursos respondia à crescente demanda por profissionais qualificados na área, convém refletirmos: Como o ensino em nossos cursos se adéqua a tal exigência? Como responde à heterogeneidade e às expectativas de alunos e professores, especialmente após o aumento de pessoas oriundas de grupos historicamente excluídos da educação superior? Como esse cenário impacta nosso senso comum disciplinar acerca do que faz um cientista social? 
A extensão, por exemplo, ganha um especial relevo nos artigos - justamente a atividade menos prestigiada nos grandes centros universitários, se comparada com a pesquisa e o ensino. Foi pela extensão que Thais Brito conseguiu se inserir na cidade de Santo Amaro e vincular seu objeto de pesquisa - o bordado - às trajetórias de mulheres do Recôncavo Baiano. Flavia Melo e Rodrigo Reis produzem uma brilhante descrição sobre os efeitos decisivos da presença de indigenistas e filhos de lideranças indígenas como estudantes da Ufam para a realização de um projeto de extensão voltado ao assessoramento de organizações indígenas. Esse projeto de extensão promoveu uma incontestável abertura da universidade à comunidade externa e, ao mesmo tempo, foi um catalisador de novos projetos e intervenções.

Estes projetos de extensão, assim como as outras experiências de ensino, estão no cerne da experiência pedagógica de professores e estudantes nos novos contextos da educação superior. O que significa ministrar antropologia rural para filhos agricultores, que reconhecem complexos conceitos antropológicos a partir de experiências vividas, como descreve Leal? Ou as "caminhaulas" e "ecopedagogias" empreendidas por De Luca e Buti com estudantes quilombolas e africanos, que revelam a potencialidade transformativa de outras formas de ensinar e de aprender antropologia, quiçá, colocadas de maneira mais urgente nas novas universidades do interior do país? Concomitantemente, estas experiências apontam para a necessidade de ações mais amplas e mais criativas para atender o perfil cada vez mais diversificado dos novos estudantes (e dos novos professores!). Por isso mesmo, sugerem, igualmente, atentarmos a situação dos docentes, cuja permanência nesses novos campi demanda ações que extrapolam as formas tradicionais de fomento dirigidas à pesquisa, ao ensino e à extensão.

Conforme já afirmamos, a expansão e interiorização das universidades é imperativa, mas ainda não está completa. Os desafios e tensões apresentadas nesse dossiê colocam mais questões do que propriamente uma palavra final sobre o assunto. Como consolidar a expansão e a interiorização em meio aos cortes brutais e sucessivos no orçamento e que impactam diretamente novos cursos em novas universidades em contextos interioranos? Como estimular a permanência de novos docentes em municípios que contam com infraestruturas precárias ou insuficientes para atender demandas como saúde, educação escolar, serviços de transporte e de comunicação? Como assegurar a permanência e a inclusão com vistas a conter a evasão dos novos estudantes? Como consolidar a política de assistência estudantil para além dos cursos e das instituições e envolver também as prefeituras, os governos estaduais e outras fontes de financiamento do Governo Federal?

Ao se debruçarem sobre suas experiências como professores e antropólogos e ao produzirem relatos sensíveis sobre as condições em que realizam seu trabalho em locais geográfica e simbolicamente distantes, os autores e autoras aqui reunidos nos fazem lembrar de divisores muito presentes no nosso fazer acadêmico (nós x os outros, ciência x conhecimentos tradicionais, técnica x política) que a vida nos novos campi e universidades atualizam incessantemente. Assim, nossa 
reflexão sobre novas universidades, novas alteridades e novas formas de docência na antropologia é, antes de mais nada, um convite para novos diálogos no embalo da expansão da educação superior e a criação de cursos de graduação que contam com antropólogos e antropólogas em seu corpo docente. Estas novas realidades ampliam o desafio do ensino, da pesquisa e da extensão de antropologia, seguindo aquilo que parece ser o destino manifesto do pensamento antropológico, pois, como afirmara Lévi-Strauss (2013) [1952], a diversidade e, por sua vez, as diferenças, são imanentes às conjunções e coalizões em torno de ampliar o reconhecimento do quão múltiplos somos.

Recebido: 06/10/2020

Aprovado: 08/10/2020 


\section{Referências}

ALMEIDA, Alfredo Wagner Berno de. Os programas de Pós-graduação em antropologia na Amazônia. Rio de Janeiro: ABA Publicações, 2019.

BARBOSA, Maria Lígia de Oliveira (Org.). Apresentação. In: A expansão desigual do ensino superior no Brasil. Curitiba: Appris, 2020.

BRASIL. Instituto de Política Econômica Aplicada (Ipea); Ministério do Desenvolvimento Regional (MDR). Chamada de artigos. Proposta de publicação de livro "O papel das instituições de ensino superior na interiorização do desenvolvimento brasileiro". Brasília: Ipea/MDR, 2019. Disponível em: https://www.ipea.gov.br/portal/images/stories/ PDFs/proposta_de_livro_sobre_o_papel_das_ifes_na_interiorizacao_do_desenvolvimento_brasileiro_01_agosto.pdf. Acesso em: 10 set. 2020.

BRASIL. Instituto Nacional de Estudos e Pesquisas Educacionais Anísio Teixeira (Inep). Censo da Educação Superior 2018: notas estatísticas. Brasília: Inep/MEC, 2019.

LÉVI-STRAUSS, Claude. Raça e história. In: Antropologia Estrutural II. São Paulo: Cosac \& Naify, 2013 [1952]. p. 337-378.

MACHADO, Igor José de Renó. Opulência e escassez. Sobre os egressos dos doutorados em Antropologia no Brasil (2004-2012). In: SIMIÃO, Daniel Schroeter; FELDMAN-BIANCO, Bela (Org.). O campo da antropologia no Brasil: retrospectiva, alcances e desafios. Rio de Janeiro: Associação Brasileira de Antropologia, 2018.

SANTOS, Clarissa Tagliari; LIMA, Raquel Guilherme de; CARVALHAES, Flávio. O perfil institucional do sistema de ensino superior brasileiro após décadas de expansão. In: BARBOSA, Maria Ligia de Oliveira (Org.). A expansão desigual do ensino superior no Brasil. Curitiba: Appris, 2020.

SIMIÃO, Daniel. S.; FELDMAN-BIANCO, Bela (Orgs.). O campo da antropologia no Brasil: retrospectiva, alcances e desafios. Rio de Janeiro: ABA, 2018.

VEGA SANABRIA, Guillermo; DUARTE, Luiz Fernando Dias. O ensino de Antropologia e a formação de antropólogos no Brasil hoje: de tema primordial a campo (possível) de pesquisa (antropológica). Revista Brasileira de Informação Bibliográfica em Ciências Sociais - BIB, n. 90, p. 1-32, 2019. 